\title{
Northeastern Journal of
}

\section{Agricultural and Resource}

Economics

Nutrient Application and Water Quality/McSweeny and Shortle Economic Threshold for Weeds/Marra, Gould, and Porter Nonrobustness of Dynamic Dual Models/Howard and Shumway Impact of Ice-Minus Bacteria/Love and Lesser The Distribution of Fresh Fruit and Vegetables/Beilock and Portier Factors Influencing Solid Waste Generation/Epp and Mauger Cooperative Approaches to Groundwater Treatment/Klinko and Abdalla Gender's Role in Manuscript Acceptance/Harper and Willis

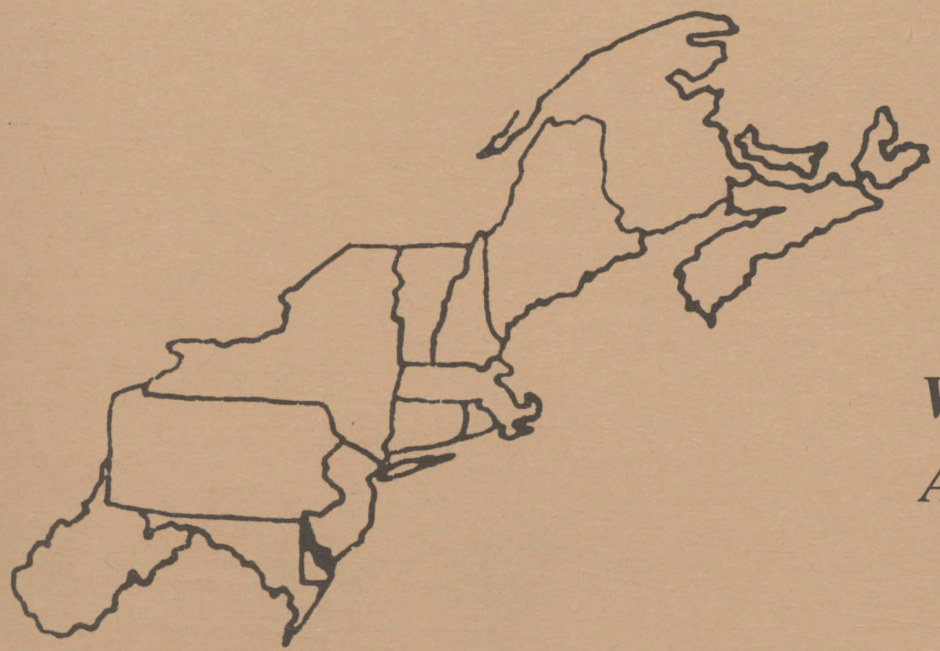




\title{
NORTHEASTERN JOURNAL OF AGRICULTURAL AND RESOURCE ECONOMICS
}

\section{VOLUME 18, NUMBER 1, APRIL 1989}

\author{
James W. Dunn, Editor
}

EDITORIAL BOARD

\author{
Ronald Cotterill, Connecticut (1989) \\ David Lee, Cornell (1990) \\ George McDowell, Virginia Tech (1989) \\ C. Edwin Young, ERS, USDA (1990) \\ James Shortle, Pennsylvania (1989) \\ Conrado Gempesaw, Delaware (1991) \\ Anwarul Hoque, ERS, USDA (1990) \\ Rigoberto Lopez, Rutgers (1991)
}

James Opaluch, Rhode Island (1991)

\section{PRESIDENT \\ PRESIDENT-ELECT \\ SECRETARY-TREASURER}

\section{ASSOCIATION OFFICERS}

John W. Malone, Jr., Pennsylvania

Cleve E. Willis, Massachusetts

Mary Templeton, West Virginia

\section{EXECUTIVE COMMITTEE}

Marilyn Altobello, Connecticut Lorna Aldrich, USDA

Bradley Cilley, C.R. Bard, Inc.

Donn Derr, Rutgers

James Dunn, Pennsylvania

Donald Epp, Pennsylvania
Bill Lessley, Maryland

John Malone, Pennsylvania

James Opaluch, Rhode Island

Neil Pelsue, Vermont

Stephen Reiling, Maine

Mary Templeton, West Virginia

Cleve Willis, Massachusetts
The NJARE is the official publication of the Northeastern Agricultural and Resource Economics Association (NAREA). The purpose of the Journal is to foster and disseminate professional thought and literature relating to the economics of agriculture, natural resources, and community development. It is published twice a year-in April and October. In addition to normal refereed articles, it also publishes invited papers presented at the annual meetings of NAREA as well as abstracts of selected papers presented at those meetings. Membership in the NAREA is open to all persons having an interest in agricultural and resource economics. Membership dues include subscription to the NJARE and are $\$ 15.00$ per year regular and $\$ 5.00$ per year student. All other subscriptions are $\$ 15.00$ per year. Single copy prices are $\$ 7.50$ per issue.
Address all new manuscripts and editorial material to

Loren Tauer

452 Warren Hall

Cornell University

Ithaca, NY 14853

Address requests for membership, subscriptions, and changes of address to

Mary Templeton

Division of Resource Management

West Virginia University

Morgantown, WV 26506. 


\section{Contents}

Reducing Nutrient Application Rates for Water Quality Protection in Intensive Livestock Areas: Policy Implications of Alternative Producer Behavior/William T. McSweeny and

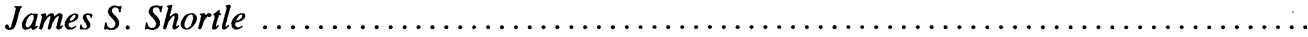

A Computable Economic Threshold Model for Weeds in Field Crops with Multiple Pests, Quality Effects, and an Uncertain Spraying Period Length/Michele C. Marra, Thomas D. Gould, and Gregory A. Porter

Nonrobustness of Dynamic Dual Models of the U.S. Dairy Industry/Wayne H. Howard and C. Richard Shumway

The Potential Impact of Ice-Minus Bacteria as a Frost Protectant in New York Tree Fruit Production/John Love and William Lesser

Using USDA Fresh Fruit and Vegetable Arrivals to Determine the Distribution of a State's Production/Richard Beilock and Kenneth M. Portier.

Attitudes and Household Characteristics Influencing Solid Waste Generation: A Household Garbage Analysis/Donald J. Epp and Paul C. Mauger

Cooperative Versus Individual Approaches to Treatment of Contaminated Groundwater by Rural Residents in the Northeast/Deborah K. Klinko and Charles W. Abdalla...

Gender's Role in Manuscript Acceptance: Sex in the Journal/Carolyn R. Harper and Cleve E. Willis 